\title{
International Survey in Eight Countries about Teachers and Teaching Profession
}

\section{Belgium, Cyprus, Italy, Libya, Poland, Slovakia, Turkey, United States of America}

\author{
Sandra Chistolini
}

Abstract: An international team of experts from Belgium, Italy, Poland, Slovakia, Turkey and the USA employed a questionnaire to identify the deontology of teachers from infant to secondary school in eight countries. The survey was implemented between 2004 and 2007. The socio-cultural concept of Verstehen (understanding) as described in the work of Max Weber, points to the clear significance of being a teacher at this time in history. Qualitative and quantitative analysis allow for an understanding that the teacher is exactly that, in any context. The ideal typology of the teacher is the result of training at a university level and working in the school system. Phenomenal differentiations characterise the various situations and broaden the perspective of the study, including an identification of the shared features of the profession. The strong, common core is the responsibility towards fellow teachers balanced out by a weak, yet common note of regret regarding the scant social prestige of being a teacher. There seems to be a lack of communication between the personal and social aspects involved in shaping the professional identity. The social image of teachers weighs heavily on their professional status due to the inevitable political implications it results in and the considerable effect on institutional behaviour. Teachers listen, but they are not heard; teachers are committed, but remain unrecognised; teachers evaluate, but are evaluated in turn. The issue of the social importance of the profession of teachers in our societies emerges as a crucial point in the perspective of educating young generations.

Key words: Teachers, deontology, professional status, social prestige, identity.

\section{Introduction}

This article highlights some of the findings of some international research into the professional status of teachers, published in 2009 as a book in two languages, with a CD available. 
In this article, we present some of the results of a survey that was conducted in eight countries on sample groups of teachers working at various levels in education, from nursery school to upper secondary school. Collaborative research was conducted in the following countries (the number of teachers involved is indicated in parentheses after each country): Belgium (72), Cyprus (40), Italy (1265) and Libya (45); independent research was carried out in Poland (147), Slovakia (97), Turkey (202) and the United States of America (180). The questionnaire was translated into the different national languages and was given out at various times between 2004 and 2007. Since no funding was available, the teachers volunteered their time and dedicated extra work hours to this project, after their normal duties at school and university.

This is not a comparative, cross-cultural study; the results refer to selected sample groups and the data obtained cannot be generalized. It is a qualitative survey, of an exploratory character and an inclusive nature and has training value.

It is qualitative in the sense that the questions in the questionnaire are derived from hypotheses of work that were verified by means of answers and the answers allowed new questions to be formulated. For example, an initial hypothesis was the assumption that the professional identity of a teacher is developed through university studies. On the other hand, a final hypothesis was that professional ethics is essential to understanding the socio-cultural status of the teacher. Professional ethics is not studied at university as a subject; it is learned during the process of teaching.

It is an exploratory survey since it points out the characteristics of the professional aspect of teachers, in each country, who were again nominated to selected groups of teachers to be given the chance to discuss and acknowledge their educational and professional role.

It is an inclusive survey in the sense used by Max Weber [1922]. We wish to throw light on the human behavior of teachers and comprehend it by pointing out connections and regularities, by trying to understand (Verstehen) why teachers attribute certain meanings to their profession and what these meanings are at the moment they are detected. We will then be able to define a single typology with several teaching models.

It is a training survey since the closed questions on the questionnaire have been formulated using statements developed together with the teachers prior to being written into the work tool. The teachers participated in setting up the questionnaire and played a teacher-researcher role in the democratic process of the on-the-job self-training.

The teachers responded in relation to a questionnaire of 42 closed questions; for each item they replied by choosing a degree of agreement on a scale 
of five. The percentages were then calculated and an attempt was made to understand what the teachers were communicating in their replies, to themselves and others.

The questions on the questionnaire concerned the socio-demographical data of the teachers; their university education; their reasons for choosing teaching; the characteristics of the school they work at; their relationships with pupils, colleagues, principals and parents; a personal and social assessment of their own work, their professional side in view of the past and future, career expectations and associative and political involvement.

Since we were unable to deal with the results from all the replies, we are presenting four, in particular, through graphic representations (from graph 1 to graph 4) that show the perceptions of the teachers surveyed: who is a good teacher; how are teachers defined with respect to their role; why did they choose teaching; what is their social prestige. In general, we can say that all the teachers, with differing intensity, chose items that qualify them as "good" because they involve the pupils in school activities, with the exception of the sample groups from Belgium and Libya for whom sensitivity to "Serious attitude toward civic and professional duties" was highest (graph 1). All of the teachers from the various sample groups, with different emphasis, deem themselves to be educators who are training new generations, rather than intellectuals committed to forming critical consciences or citizens who have chosen the profession to discharge a relevant social function (graph 2). In all of the countries selected, the teachers stated that they had primarily chosen this job because they like working with young people. Only in Libya do teachers generally state that they made the choice for reasons of public and cultural service (graph 3). As regards the assessment of social prestige, the teachers in the most critical sample groups are those around the Mediterranean area: Italy, Cyprus and Libya, for whom society is less appreciative of the contribution teachers make (graph 4). It follows that maximum agreement refers to the model of teacher-educator, while maximum disagreement concerns the perception of the social role of the teacher. Internal factors (such as subjective identification with the profession) unite the sample groups; external factors (such as social appreciation) tend, on the other hand, to diversify the sample groups within the limits of this survey.

I would like to thank Hugo Verkest (Belgium), Małgorzata Kowalik-Olubińska, Marzenna Nowicka, Elżbieta Wołodźko (Poland), Iveta Kovalčiková (Slovakia), Ahmet Aypay and Ebru Aktan (Turkey) and Christopher H. Tienken (USA) who arranged for the survey to be carried out at their universities. I am using part of those texts to portray the data collected. The data is presented alphabetically in this article starting with Belgium, Cyprus, Italy, Libya - the 
countries which worked together - and proceeding with Poland, Slovakia, Turkey, and the USA.

An especially well-deserved acknowledgement goes to Network, expertly set up by Children's Identity and Citizenship in Europe, and supported by the European Commission Erasmus Programme. This network operates within the Socrates and Lifelong Learning Programme initiatives and also represents the willingness of the participants to work together and produce thoughts that have a great educational impact.

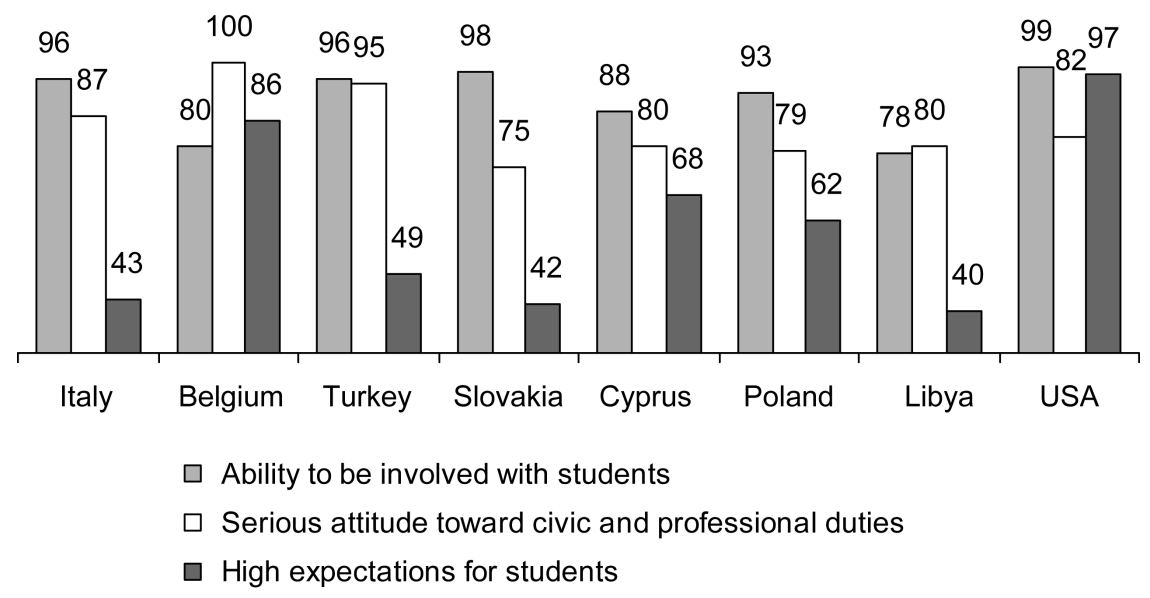

Graph 1: The good teacher in eight countries (agree + strongly agree \%)

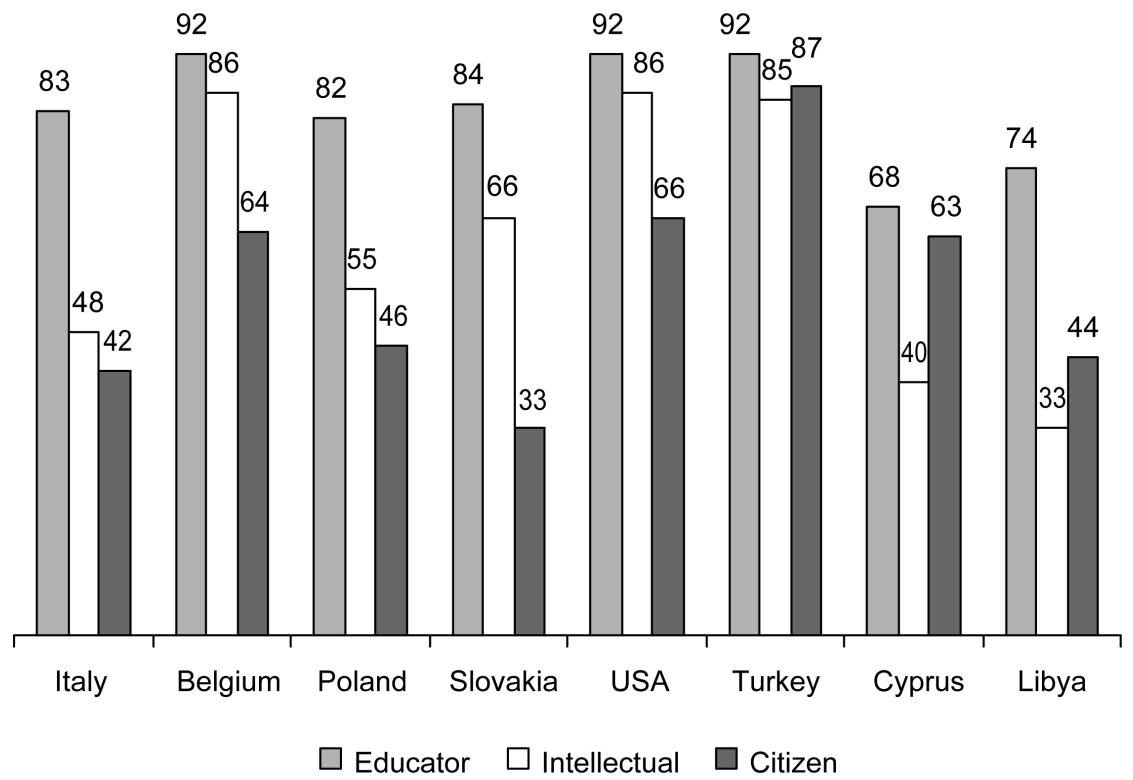

Graph 2: Descriptions of a teacher in eight countries (important + very important \%) 


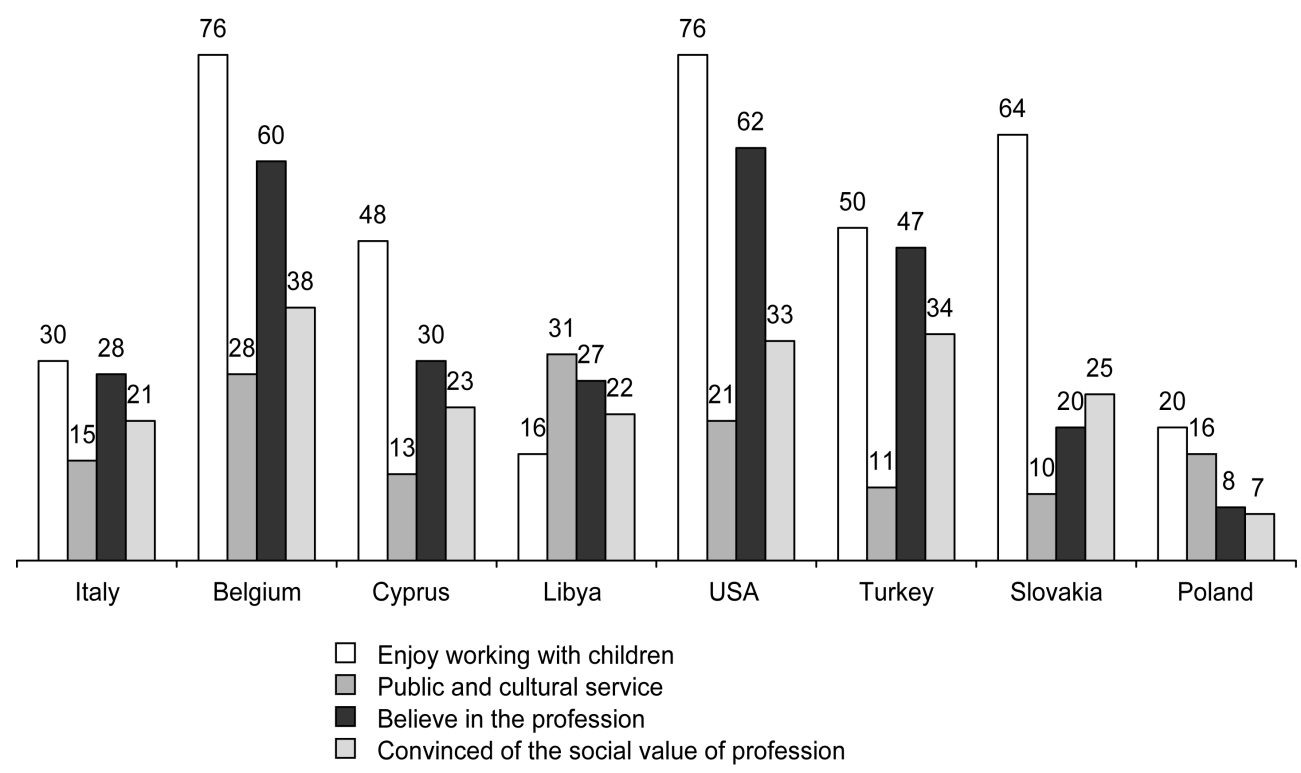

Graph 3: Reason for choosing to be a teacher in eight countries (strongly agree \%)

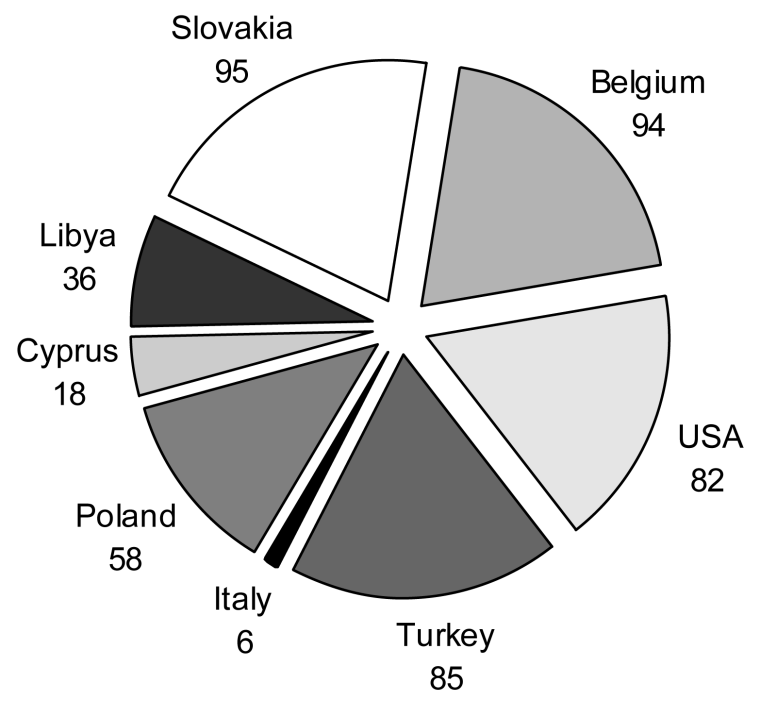

Graph 4: Social prestige of teachers in eight countries (important + very important \%) 


\section{Methodology and tools}

To collect data, the international team used a questionnaire consisting of 42 questions, initially produced by an Italian interdisciplinary research group, including colleagues from the United States (2003) and post-graduate students from Libya and Cyprus specialising in teaching, who spent a post-university training year in Italy.

The translation of the questionnaire into English, Arabic, Greek and Dutch facilitated its distribution among teachers in kindergartens, elementary and secondary schools. Nonetheless, it should be pointed out that not all of the questions on the original questionnaire, written in Italian, were easy to understand in the very different cultural contexts it was applied in. In the various countries involved in the research, the contact person was the researcher who had to read, understand, translate and distribute the questionnaire, working from the English text - the language of international communication. Any knowledge of Italian by the researcher was definitely of great help in verifying the questions posed by the questionnaire.

\section{ITALY, BELGIUM, CYPRUS, LIBYA}

\section{A new philosophy of citizenship in Italy, Belgium, Cyprus, Libya}

The research highlights a dissimilar level of social perception of the teaching role. In their profession, teachers either feel greater devotion to the community, as in Belgium and Libya, or feel separated from a social environment that does not sufficiently appreciate their work (Italy, Cyprus). Despite this double standard, it is clear that in the four countries concerned, the question of whether teachers feel they belong to the community is fundamental to their commitment to the profession and the success of the educational process. It is not enough to feel part of society; it is necessary for society to send messages of acknowledgement of the role they play and to show trust in teachers whose satisfaction is based on their work, not only on relations with alumni (Italy), but also on relations with their colleagues and the students' parents (Belgium, Cyprus, Libya).

At this time, Italy shows the least appreciation of the profession in a social sense. Within the margins of the inquiry, the reason for this can be attributed to the low degree of attention paid to extended social relations with colleagues, families and local organizations. Italian teachers invest in their qualifications and, if well prepared, do not concern themselves enough with showing what they are capable of doing outside the school. However, this fact also lends itself to another interpretation. Perhaps Italian teachers are not 
interested in showing their abilities outside the school, which does not help society to decipher the skills of teachers working within their institutions.

In reading the profile of the teacher, Libya and Cyprus appear to be two particularly interesting cases. In Libya, the teacher (usually male) is principally considered to be an intellectual engaged in shaping critical awareness and to be a citizen who is open to the social responsibility of his role; in Cyprus, a teacher is, first of all, a person who contributes to the education of upcoming generations and a citizen who has chosen to teach in order to perform a relevant social function. In Libya, public recognition is most important; whereas in Cyprus it is the content. The perspective of a socialist state is compared to the perspective of a state that is still strongly idealistic. In Libya, a person has a social value before they have an individual value, whereas in Cyprus, the political situation of the small divided country can only be sustained by cultivating the idea that change will come and bring families together again. The idea of a better future bolsters the hopes of younger generations.

From this point of view, Italy and Belgium find themselves in two opposite situations. The realism in Italy corresponds to a certain conservatism in Belgium. Not only is there a practical separation between educational and political conservatism, but there is an inverse relation between educational and political liberalism. Educational liberalism is a sure means for preserving the social status quo, whereas the best practices of educational conservatism are the only means whereby children from disadvantaged homes can secure the knowledge and skills that will enable them to improve their condition [Hirsch 1996]. In Italy, teachers risk being excluded even more from the community, feeling forced to perform tasks like an ordinary worker who earns a living by teaching, rather than participating responsibly in the social growth of the school. In Belgium, on the other hand, the opposite situation is encountered: the distance between the teachers interviewed there and the image of the teacher-worker in Italy is quite evident. The realism in Italy is derived from the ascertainment of the low social reputation of teachers who end up carrying out their jobs without even believing in the possibility of generating substantial improvements in their working conditions. The conservatism in Belgium is the result of the confirmation of the social importance of teachers who carry out their work surrounded by a feeling of trust and therefore do not perceive any obstacles from society. In Belgium, teachers are the educators of the younger generations, thus confirming the traditional role that society fully recognizes.

Verkest [2003] underlines the fact that until 1960, Belgian male teachers combined their studies at the teacher training college. They were teachers and also worked as sextons, organ-players or surveyors. Most of them were 
even active members of religious and cultural organizations. So the perception of a male teacher was and still is that of an omni-valent person and a good and honest citizen greatly involved in society. Teachers are still asked to participate in counting the votes in elections or to be chairman of a polling station. Male students have more possibilities or chances of finding a job more quickly than their female colleagues.

Belgian researchers located the conservatism in the religious context of the school. Catholic schools represent $75 \%$ of all schools. In the near future there will be more investigation into the statement: Work should always come first, even if this means less leisure time. Teachers want to have a more 'expressive work orientation' and this is in combination with responsibility, creativity, developing their own capacity, team work.

Most of the school reforms in Belgium are situated in the context of "needs for pupils' and that is the reason why teachers want to accept this challenge. So they take up more tasks and have more meetings to support pupils and parents. The risk of losing their status as teachers who are 'good enough' is always on their mind [Ballet 2005; Burggraeve 1985]. To survive all kinds of social reforms, teachers qualify the call for reforms by giving meaning based on their personal ideas or perspectives. This process involves reflecting on an individual's philosophical foundation and a certain level of self-determination.

With respect to the hypothesis of the social deprivation of teachers, in all of the countries surveyed, this question has a certain relevance in fostering a feeling of belonging and both schools and societies will have to commit themselves to this aspect. To feel one belongs to a community is the starting point for building significant, long-lasting social ties. The social fabric is reconstructed through communication among the people who live together and decide to contribute to the progress of humanity by investing in schools and families. The politics of a state directed at well-being foresees the participation of citizens who have matured their public spirit for the common good. Families and schools are the fundamental units in which one learns to love one another, help one another and be united in order to then carry these feelings over into the wider social framework. The complexity of family life and the vulnerability of young people give teachers the status of a third adult.

The new philosophy of citizenship is that of the reciprocal understanding of the overall values in which each person can recognize that he or she belongs to a common totality. Most changes in our educational organizations occur without the reflection and participation of parents and pupils. Schools neglect the voices of parents and pupils and this is an important factor in the promotion of active citizenship. Most educational changes are, from the pupils' perspective, non-participatory. An increasing number of schools are in- 
terested in European projects like Comenius and in Belgium there is a tendency for schools to "show off their participatory activities with some 'special groups' to the local community through the press. The international comparison of shared issues raises awareness of a common belonging to a worldwide community. The process of belonging is sometimes affected by consumerism. The greatest potential benefit for teachers is the emergence of educative communities [Goodlad 1994]. Instead of feeling isolated, teachers who become part of these communities and participate in professional developments become members of a larger sustained community of educators, which affords them the opportunity to encourage and support each other's efforts.

A humane future develops in a climate of peace and freedom. Peace, the result of agreement between persons of good will, and freedom, the drive towards the development of people who communicate, use the language in which they can best express their humanity. This idea of the citizenship of a person originates in schools, with teachers who have experienced, firsthand, the meaning of belonging to a community, of human communication, and agreement among peoples. Belonging, communication, agreement - these form the structure of the reciprocal understanding of common values, first of which are the values of justice and awareness. Justice of being what we decide and knowledge of doing what we can manage.

\section{POLAND}

\section{Social perception of teachers in Poland}

In Poland the teacher is expected to be aware of the connection between the school and the society, to perceive themselves and their students as participants and creators of social transformations. Therefore, the skills that are particularly desirable among contemporary teachers include reflectiveness, social and cultural sensitivity, autonomy, creativity and responsibility [Gołębniak 1998; Kwiatkowska 1997; Mizerek 1999].

The turning point in shaping teachers' awareness was the political transformation. This brought new opportunities for autonomous and creative activity, manifested in numerous new educational initiatives, such as establishing non-state schools, implementing alternative curricula and teaching concepts, forming associations that promote the development of education, issuing new journals for teachers and setting up new educational publishing houses. The initial enthusiasm on the part of the teachers was often watered down by governmental directives and verified by Poland's new social and economic conditions. In 1999, a large-scale reform of education was initiated. Apart from radical changes in schools with respect to their structure, man- 
agement and financing methods, as well as to the curriculum and the system of examinations, a new path for teachers' professional development was established. The changes to procedures for promotion were designed to increase the social status of this professional group, but above all to expand the range of professional competences required from teachers by modern society.

At present, a teacher's professional career consists of five stages: teacher trainee, contract teacher, nominated teacher and certified teacher. At the very top of the professional career is the title of honorary professor of education, which is granted in recognition of exceptional educational achievements.

The reforms determined the new way in which teachers are supposed to function, which has presumably affected their perception of themselves and their chosen profession. The research enabled us to establish the opinions of Polish teachers on various aspects of their professional role. Special emphasis was laid on the teachers' motivation to work, their vision of a good teacher and good teaching as well as their professional and social function, their social perception as a professional group.

M. Kowalik-Olubińska, M. Nowicka, E. Wołodźko conducted the study in Poland with the participation of 147 teachers from all levels of the Polish school system. The largest group comprised kindergarten teachers (30.6\%), somewhat smaller groups consisted of teachers of middle schools (23.8\%), secondary $(21.1 \%)$ and primary schools $(18.4 \%)$, the smallest group being university lecturers (6.1\%).

The profession of teacher in Poland is largely feminised, which is evident from the make-up of the study group: $78.9 \%$ of the respondents were women, and only $21.1 \%$ were men.

Nearly all the teachers held degrees: $8.8 \%$ held bachelor degrees, and $87.8 \%$ masters. It is worth noting that a significant group (53.7\%) are pursuing post-graduate studies.

The participants represented all the different stages of the profession. The smallest group (8.8\%) consisted of trainees and the largest (42.2\%) - nominated teachers. Contract teachers constituted $13.6 \%$, and certified teachers $33.3 \%$. The results clearly demonstrate that a third of the study group had achieved the highest level of professional development, which is closely connected with work experience. Nominated teachers would have worked in educational institutions for at least 6 years, and certified teachers for at least 9 years. In the group surveyed, the percentage of such teachers was as high as $75.5 \%$.

The respondents had an opportunity to evaluate the factors that affect the social perception of their professional group. According to the respondents, 
by far the most important factor that affects the social perception of their professional group is the level of remuneration. This opinion was expressed by all the respondents. Other crucial factors include building positive relations with students, parents and the local community (98\%) and effective teaching (97.9\%). The issues of the social importance of the profession and teachers' professional development are viewed as only slightly less important $(82.3 \%$ and $81.7 \%$ ). The results presented in the diagram indicate that the category of "rigorous evaluation of teachers (accountability structures) and student achievement (test scores)" was viewed as relatively less important (66.0\%).

The group of teachers expressed their opinions on the social image of the profession. A significant percentage $(57.8 \%)$ would like to see an improvement in the way that they are perceived, which may imply that teachers tend to perceive their social position as unsatisfactory and would like it to be enhanced. Perhaps the reason is that remuneration of Polish teachers is relatively low, and as the details in the diagram above indicate, the respondents feel that financial reward is the most important factor that affects the perception of teachers in society.

The questionnaire asked the teachers to specify how they should be perceived by society. The respondents believed above all that teachers should be viewed as highly qualified specialists. This is the most important factor for $100 \%$ of the group under survey. It is also important for teachers to be perceived as persons who perform their social function to the best of their ability $(89.8 \%)$ and who participate in the education of the new generation (81.7\%). Teachers should also be perceived as persons who make a living teaching others (67.4\%). This belief corresponds to the aims of the profession discussed earlier. Contemporary teachers do not wish to sacrifice themselves in the name of 'higher ideals' and treat their profession rationally, as just another method of satisfying economic needs. The respondents also thought that it was important for society to perceive teachers as experts who educate highly-qualified employees (61.3\%).

If we consider the survey in Poland in its entirety, then we see from the responses provided that a certain image of the profession of teacher in Poland emerges, which is characterised by the following aspects amongst others:

- The profession of teacher in Poland is largely feminised.

- Teachers are well-educated, and the majority of those surveyed are improving their qualifications through post-graduate studies.

- What motivates them to pursue the profession is the need for personal development, the joy of working with children and taking advantage of an opportunity. 
- A good teacher, above all, should be able to effectively manage the class, motivate their students to work and should be well-prepared to teach their given subject.

- Good teaching is based mostly on the teacher's pedagogical competences and organisational skills.

- The most important competences required from teachers at each stage of their professional development include creating positive relations with students and the methods and pedagogy. Cultural and ethnic sensitivity are not fully appreciated.

- The respondents believe that the social perceptions of their profession largely depend on the level of remuneration. It also depends on their competence in building positive relations with students, parents and the local community as well as the ability to teach effectively.

- More than half of the respondents would welcome an improvement of the social image of the profession.

All in all, Polish teachers seem to focus on their activities within schools: they are well-prepared to teach their subjects, have a high opinion of their teaching skills and techniques, but they do not consider their profession to have a high social status and they seldom get involved in social activities. The survey reflects the way teachers see their profession in terms of the ongoing transformation of the educational system in Poland. It indicates that it is necessary to implement projects designed to educate teachers and help them become autonomous, reflective and pro-social individuals, apart from merely being good school class managers.

\section{SLOVAKIA}

\section{The profile of teacher in Slovakia}

In analysing and interpreting the data obtained, Iveta Kovalcikova, a researcher from Slovakia, created a model of the typical teacher in Slovakia:

... "She" (98\% of respondents were women) is quite passive in terms of social engagement, she is exclusively a member of community groups, teachers' associations, religious organizations connected with education; moreover, she does not belong to any professional educational organizations. (The data presented by Kovalčiková show that the majority of respondents of all types of schools are not involved in or do not work for any of the organisations indicated. The type of school does not influence the level of active participation of the respondents. Neither does the age of the teacher nor the years of teaching experience influence the level of social participation in professional bodies; teachers at all types of school are equally "passive"). 
...despite being passive, she would have much appreciated an improvement in the public perception of the teaching profession. (The same composition and diversity of teachers also applies to the following item. For a majority of respondents, raising the public's perception of teaching is extremely important. We did not register statistically significant differences in opinions of teachers of different age groups and types of school).

Irrespective of the type of school she is employed in (pre-school, elementary, secondary or other) the main motivation in deciding to become a teacher was an enjoyment of working with children. (The research results indicated that $87 \%$ of respondents considered working as a teacher during their studies).

She is strongly convinced of the social importance (value) of the teaching profession. She admits that motives such as "personal development", "public service" or "belief in the profession" were only secondary incentives to becoming a teacher. Being provided with additional free time that could be dedicated to the family is not in her view a primary advantage of taking up the teaching profession...

In the questionnaire section on "the characteristics of good teachers", the model of teacher strongly corresponds to that of the teachers:

- Should be adequately trained in a specific subject area,

- Should hold a serious attitude towards civic and professional duties,

- Has to be able to motivate and engage students in learning the process.

However, she:

- Does not necessarily need to have high expectations for the students.

Opinions on the model teacher included the following:

- a teacher's interest in the students and parents and the level of satisfaction with their school are only of partial importance for "good teacher's behaviour",

- the model teacher agrees that the "quality of teacher" is connected with the student's performance in both state and standardized tests (this fact deserves further analysis as Slovakia has not developed enough of a tradition of state or national standardized testing). She only partly agrees that in order to achieve the status of "good teacher" extra time must be dedicated to the students, over and above routine teaching duties. The model teacher generally agrees that a good teacher is one capable of team working with colleagues and recognizing each student's potential to meet their individual needs, but she only partially agrees that a "good teacher" must believe in the school for which he/she works (this item could be a matter of discussion, due to the fact that the teachers in Slovakia have not yet developed a strong feeling of belonging to the school community as a result of the former socialist regime). 
A model teacher considers changing employers from time to time, but not frequently. Reasons for changing jobs are:

Primarily and urgently:

- The need for greater financial support.

- A lack of gratification on professional and cultural levels.

- Poor career prospects.

In part:

- She has lost motivation and sometimes experiences fatigue and burnout.

\section{TURKEY}

\section{Turkish teachers and classroom management}

Almost one-third of all civil servants in Turkey are teachers. This number does not include part-time teachers. Teachers in Turkey, as in other countries around the world, represent middle class values. The status of teachers and the teaching profession has always been discussed. Recently, there has been a move to increase the status of teachers in Turkey. For example, following the 2001 economic crisis, teacher training institutions increased admissions and started admitting more qualified students. Students learnt that there is relatively higher job security in the teaching profession. Secondly, as the race to get into universities becomes harder, teachers are more likely to benefit from this. The reason is that private spending (not public) in Turkey is among the highest in Europe. The World Bank highlights this fact. Moreover, Turkey reformed teacher training in 1998. As a result, students who would like to be teachers receive one or one and a half years more schooling. It means that they have to go to school for five or five and a half years and obtain a masters degree. This has also raised the status of the teaching profession in Turkey. It will be interesting to see the status of the teaching profession and teachers in relation to these changes that have taken place since the late 1990s. Turkey is a candidate country currently in negotiations for full membership to the European Union.

In 1982, universities became responsible for teacher training at all level of schools. Initially, the universities were not prepared for training the teachers. The lack of faculty members, the high number of students, and the lack of physical resources all led the universities to complain about teacher training institutes. The Ministry of Education withdrew from teacher training. There was no connection between the universities that train teachers and the Ministry of Education that employs teachers

Studies were carried out to measure the effects of these re-structuring efforts. Many were critical of this re-structuring; however, much of the criti- 
cism was not confirmed by empirical findings. Two studies by A. Aypay and Kalayci [2008] and Grossman and Sands [2008] measured the effects of the re-structuring. Both studies found that the re-structuring was incomplete. Greater effort was required to complete some areas such as teaching methodologies.

A. Aypay and E. Aktan considered 202 teachers for this comparative survey. The age distribution of the sample is as follows: almost a fourth of teachers are 23 years old or younger, $40 \%$ of them are between 26 and 35 years old, approximately one-fifth of teachers are between the ages of 36 and 45 and the last fifth are 46 years old or more. These figures indicate that almost two-thirds of teachers in the sample are 35 years old or younger. The gender distribution of teachers in the sample indicates that while almost one-fifth of teachers are male the rest are female. This figure is consistent with the female domination of the teaching profession in Turkey (78\%) similar to elsewhere in the world. Almost a third of teachers in the sample work in pre-schools and kindergartens while almost 40 percent teach in elementary schools (grades 1-5). Another 13 percent are at primary school (grades 6-8). Overall, half the teachers in the sample work at primary schools (grades 1-8). This distribution is consistent with the overall distribution in Turkey where the great majority of teachers are at elementary schools. While ten percent of teachers work at high schools, only three percent of teachers teach at specialized schools.

The Turkish teachers teach because they seem to enjoy working with children, believe in the profession and are convinced of the social value of the profession. These three questions were most frequently answered. Almost $80 \%$ of respondents selected the agree and strongly agree options. Teachers in Turkey seem to choose teaching because their concern is primarily related to personal feelings and beliefs. There is also a social value to the profession as well. However, personal feelings and beliefs seem to be more important.

Teachers are satisfied with their principals and colleagues. More than half of teachers are satisfied with the achievement levels of their students. Teachers seem to be dissatisfied with parental involvement and their relationships with students on the personal level. This may indicate that relationships between teachers, parents and students are formal. Teachers in Turkey are not very satisfied with teachers' unions. This may be because teachers' unions are ideologically and politically oriented. Unions divide teachers into camps and there are many unions. Teachers are not very satisfied with the local educational authorities. This may be a result of the highly centralized educational system.

Teachers in Turkey see the social function of education as the most important factor in defining a teacher. Teachers are also defined in terms of social 
consciousness and equality of educational opportunity. Thus, the social value of education is more important than the others.

Teachers in Turkey ascribe great importance to describing what good teaching is - the ability to communicate effectively, effective classroom management and appropriate instruction, lesson preparation, and pedagogical competence They emphasize the importance of classroom management skills and training in education sciences. Teachers see themselves as not only educationally but also socially responsible for students. While teachers have been satisfied with their colleagues in their immediate environment, they are not happy with the local and central educational authorities. This may be a consequence of the highly centralized educational system.

\section{U.S.A.}

\section{Job-embedded professional development in the United States of America}

Education leaders in the United States (US) seek interventions that will improve teaching and student learning. Reauthorization of the federal 1965 Elementary and Secondary Education Act (ESEA PL89-10), known as the No Child Left Behind Act of 2002 (NCLB, PL 107-10), brought renewed national attention to achievement differences among sub-groups of students (blacks, whites, Asians, students in poverty) and increased the need to find successful interventions. The NCLB Act requires educators to engage in scientifically-based research (SBR) practices to raise student academic achievement. Educators and politicians often cite in-service training and professional development as scientifically-based remedies for what ails American education. The US government has included in-service and professional development requirements for teachers in every piece of major education legislation during the past 50 years.

C. H. Tienken provides definitions of the terms in-service, staff development, professional development, and job-embedded professional development to facilitate the discussion.

In-service training: one-time or short-term training, usually a specific workshop or large-group session to present information or a basic skill, easily learned, usually delivered via one-way communication. There typically is no follow-up. The term is "left-over" from earlier times in education history when "in-service" teachers received top-down training.

Professional Development refers to ongoing education through which certified education professionals learn processes that relate to classroom instruction and focus on improved performance of professionals and their students. It is planned and long-term. 
Staff Development is similar to Professional Development except that the audience or target group could include paraprofessionals and non-certified personnel who work with students.

Job-Embedded Professional Development is continuing education that occurs in the context of the classroom and focuses on teacher behaviors related to instruction and student learning. Teachers learn by doing. They work together in small groups $(n<15)$ to study the problems and challenges of teaching. Teachers reflect upon their work and make informed decisions about teaching. Structures may include action research, peer coaching, or structured study groups.

Our exploratory study investigated the types of professional growth opportunities that teachers with various years of experience (i.e. pre-service, one to three years experience, and greater than three years experience) determined to be important for professional growth. The study was inspired by the professional growth opportunities conducted during the Eight-Year Study and it was guided by the overarching question: What professional growth opportunities do teachers think are important for their growth? Two specific questions guided the methodology of the study: 1) What types of opportunities do teachers, with various years of experience, think are important for their professional growth? 2) What types of opportunities for professional growth do first-year teachers think are important during the first three years of the profession?

The results suggest that the types of professional growth opportunities teachers think are important go beyond the workshop topic and transcend grade levels and years of experience. Teachers responded positively that a climate for growth must exist in the school building to compliment the actual training topics and training structures. The data also suggest that teachers think professional growth can occur outside of the constraints of the formal workshop; growth can be job-embedded. The data demonstrated that teachers want ongoing administrative and collegial support. Teachers responded that the opportunity to work with a principal that buffers environment pressures, sets expectations, understands and discusses instructional issues is an important growth opportunity.

Readers should not compartmentalize the results and conclude that a supportive principal or a collegial school, in isolation, will provide appropriate growth opportunities. It is probably more likely that the interaction of opportunities produces the greater chance of high quality professional growth. For example Randi, Ziechner [2004] and Rowan and Miller [2006] found no evidence to suggest that principal support by itself impacts teacher behaviour or student achievement. They stated it may be the interaction of leader- 
ship factors that have the greatest impact on teacher behaviour and student achievement.

Education policy makers should take notice of the teachers' responses about important opportunities for professional growth and the knowledge dynamic surrounding the reasons why they leave the profession (e.g. lack of administrative support, lack of input). The two highest rated opportunities, a supportive school and a supportive principal cannot be mandated or legislated from the US Congress or any other branch of government. Those opportunities are more likely to be born from effective school district and building level leadership (school principal) than from US or state government professional growth mandates.

Likewise, teachers responded strongly that they should have input and some control over their professional development and they want the professional development to be ongoing, not just one-day events without follow-up and support. Again, these opportunities are partly a function of the leadership provided by the school principal. The school principal has some control over professional development - the way it is structured, the resources, who has input, and how often it can take place. For example, professional growth opportunities need not be limited to one or two days a year. Building level leadership (the principal) can restructure schedules and redistribute resources to foster ongoing peer-coaching, action research, structured study groups, or other job-embedded, collegial growth opportunities regardless of the level of support from the federal and state government. The school principal can develop an in-house cadre of teacher leaders, instructional coaches, and learning community leaders at little or no additional costs by restructuring budgets and schedules. The school principal, along with teacher leaders, can have great influence on the opportunities for professional growth.

An immediate question readers should raise is, "Why continue to invest time and resources in in-service training and traditional professional development given its lack of demonstrated results?" One answer is that the types of opportunities teachers said were important revolve around the interaction of job-embedded professional development and a supportive principal. There is a growing knowledge dynamic that suggests job-embedded professional development can impact teacher behaviour and student achievement. However, most of the empirical studies in this area are small-scale [Harwell et al. 2000]. The growing data on job-embedded professional development suggest an overall positive impact. However, more research is needed.

Given that the interaction of job-embedded professional development and school leadership (principal, teacher leaders, mentors) fosters the opportunities that provide the greatest chance of impacting student achievement, and that they are the opportunities most highly valued by teachers, one wonders 
why the US and state governments have not provided more money nor enacted legislation to support the development of education leaders through Teacher-Leader programs and school principal preparation programs. Perhaps the money spent on strengthening the leadership corps with a greater understanding of pedagogy and adult learning theory would be better spent and have longer lasting influence on education improvement in the United States than the last 50 years of unsuccessful mandated in-service training and professional development.

\section{International research and mutual understanding}

Despite the doubts and perplexities, international research on teachers, through the use of the questionnaire, represents a valid contribution towards developing a scientific community, in which one discusses together and reaches agreements that are indispensable infor analysing, understanding and disseminating data relative to different cultural contexts.

The function of the research is certainly not to demonstrate that all people use the same language and meanings to describe their professional status. On the contrary, the research points to the multiple modes of individual perception and social standing of the teacher.

Who is the teacher in Italy, USA, Belgium, Slovakia, and Turkey? This is the question we were seeking to answer, perhaps triggering other questions that may be better investigated and specified over time.

The original idea was to set up a questionnaire in each country, talking to teachers in the country and allowing them to participate in formulating the questions. However, proceeding in this manner would have led to years of work, huge financial commitments and great reservations about the results. Then again, nothing prohibits us from starting with the results of each country in our sample group in order to generate a wide debate among the teachers and invite them to be the authors of a new qualitative survey.

In comparative pedagogy, researchers highlight how a survey among teachers is a means of training towards citizenship within the profession. The discussion about one's own identity allows us to take a step forward in the social recognition of the teaching role. 


\section{References}

Aypay, A., Kalayci, S. S. 2008. Assessing Institutionalization of Educational Reforms. In International Journal of Educational Development, 28: 723 - 736.

Ballet, K., Kelchtermans, G. 2005. Meer dan perceptie. Over de ervaring van geintensifieerde werkcondities. In Tijdschrift voor Onderwijsrecht en Onderwijsbeleid, 16 (2/3): $206-207$.

Burggraeve, R. 1985. From Self-Development to Solidarity. An Ethical Reading of Human.

Gołębniak, D.B. 1998. Zmiany edukacji nauczycieli. Wiedza - biegłość - refleksyjność. Wydawnictwo „Edytor”. In Toruń-Poznań.

Grossman, G. M., Sands, M. K. 2008. Restructuring reforms in Turkish teacher education: Modernisation and development in a dynamic environment. In International Journal of Educational Development, 28: 70 - 80.

Harwell, M. et al. 2000. The effects of teachers' professional development on student achievement in community school district: 2. Paper for the American Educational Research Association, New Orleans, LA.

Hirsch, E. D. 1996. The school we need and why we don't have them. New York, Doubleday.

Kwiatkowska, H. 1997. Edukacja nauczycieli. Konteksty-kategorie-praktyki, IBE, Warszawa.

Miller, R. J., Rowan B. 2006. Effects of organic management on student achievement. In American Educational Research Journal, 43 (2): 219-253.

Mizerek, H. 1999. Dyskursy współczesnej edukacji nauczycielskiej. Między tradycjonalizmem a ponowoczesnością. Wydawnictwo UWM, Olsztyn.

Randi, J., Zeichner, K.M. 2004. New visions of teacher professional development. In Smylie, M. S., Miretzky, D. (eds.). Developing the teacher workforce. Chicago: National Society for the Study of Education, $180-227$.

Tienken, C. H., Achilles, C.M. 2003. Changing teacher behavior and improving student writing. In Planning and Changing, 34(3-4): 153 - 168.

Verkest, H. 2003. Hector Defoort. Godsdienstig leven tijdens het Interbellum (1919 1939). In Heus, J. (Ed.), Jaarboek 2002.(10) Spaenhiers. Koekelare, 121 - 134.

Weber, M. 1922. Gesammelte Aufsätze zur Wissenschaftslehre, Tübingen, Mohr.

\section{Author}

Sandra Chistolini, Ph.D., Professor

Universitá degli studi Roma Tre

Faculty of Formation

Department of Educational Sciences

Via Manin, 53

I - 00185 Roma

Italy

E-mail: s.chistolini@uniroma3.it 